\title{
The use of soil analysis in the interpretation of an early historic landscape at Puxton in Somerset
}

\author{
S. J. Rippon, M. H. Martin and A. W. Jackson
}

\begin{abstract}
ABSYIRACT
Soils samples taken from two adjoining fields close to the village of Puxton in the county of North Somerset. WK were analysed in 1997 for healy metals, phosphorts, magnetic susceptibility and loss on ignition as part of an archaeological investigation of the origins and development of a medieval settlement. It had been argued that an oeal-shaped field next to the church was the mucleus of marshland reclamation during the early medienal period, though it was unclear whether the enclosure was occupied by a sottlement or was simply an area of embanked agricultural land. Soil chemistry shous certain elements, including phosphoms and the beavy metals (IP, Zn. Cid, Citu, etc), to be concentrated in a restricted part of the enclosure, which earthuork, resistivity and fieldualking sumeys suggest correlates with an area of human occupation associated with the damping of midden material nearby a bypothesis confirmed through excavation). This paper demonstrates the value of multifaceted soil chemistry, alongside a range of other survey methods, for characterising the nature of human activity on archaeological sites, and in the future may be used to locate previonsly unrecorded sites in more speculative landscape sureys.
\end{abstract}

KEYWORIS

North Somerset Levels, medieval settlement, soil analysis, soil chemistry

\section{INTROIOUCTION}

The association of enhanced levels of soil phosphorus with abandoned settlements has long been recognised (Bethell \& Maté 1989), the element being concentrated in domestic waste, particularly faeces, urine and wood ash, and accumulating in the soil as the result of its rapid fixation and long-term immobility. This process is paralleled by other elements, notably heavy metals, several of which similarly arrive on settlements through anthropogenic processes, resulting in zones of contamination around ancient farm sites. Other soil characteristics attrilsuted to human activity, such as soil colour, accumulations of organic material, and increased magnetic susceptibility due, in part, to fires (kilns, ovens, etc) or the presence of burned material, are also measurable by independent processes and can provide corroborating eviclence of human settlement or activity (Aston et al. 1998a; 1998b)

Puxton is situated on an area of reclaimed coastal alluvium, the North Somerset Levels, lying beside the Severn Estuary near Westonsuper-Mare (Fig. 1). This low-lying land has been partly protected from tidal inundation by a belt of sand dunes extending from the limestone promontories at Uphill, in the south, north towards other bedrock outcrops at Worlebury and Middlehope. Recent olservations at Westonsuper-Mare have established that this natural coastal barricer was in existence by the Roman period, although there is no evidence that the dunes ever extended along the stretch of open coast between Middlehope and Clevedon (Rippon 1997). The presence of a wealthy late Roman villa on the banks of the Congresbury Yeo at Wemberham implies that during the Roman period the North Somerset Levels were free from tidal inundation, and this hypothesis has been confirmed by the results of recent palaeoenvironmental work on several RomanoBritish rural settlements at Banwell, Kenn and Puxton Moors (Rippon 2000). The wholly freshwater environment that can be reconstructed on these sites from the pollen, plant macrofossils, mollusca, beetles, diatoms and foraminifera suggests that the stretch of coast, not protected by natural sand dunes, must have been blocked by a man-made earthen embankment. The work at all three sites has also shown that the coastal parts of the North Somerset Levels were once again subjected to tidal inundation during the post-Roman period with a return to saltmarsh conditions: clearly the sea walls had been breached (ibid.). Placenames and documentary evidence indicates that a second episode of marshland reclamation on the North Somerset Levels was well underway by the eleventh century, though it is unclear 


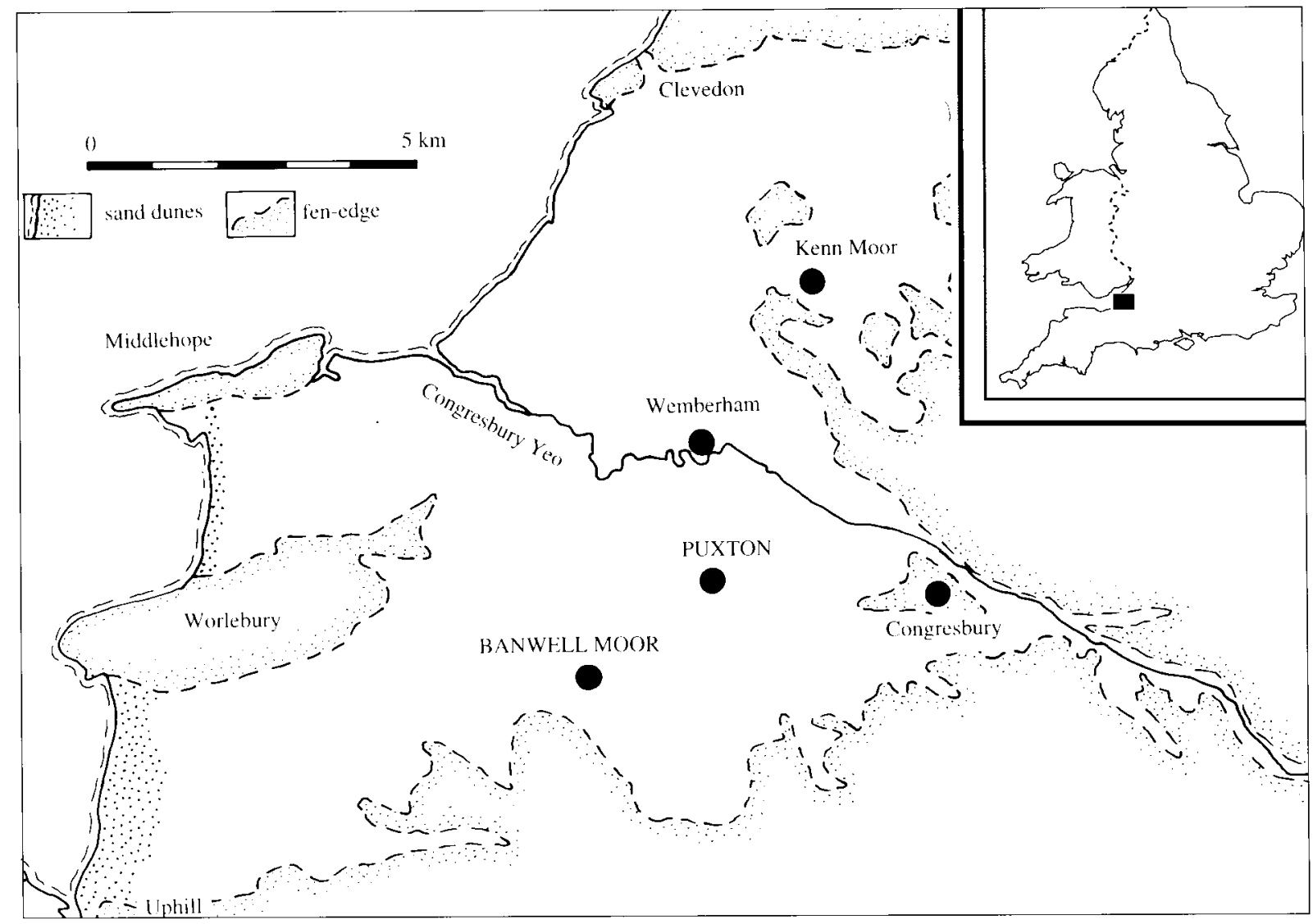

fis. 1. Puxton, on the vomb tomerset lesels.

preciscly when and how this early medicval phase of sertlement expansion took place.

In order as answer that question a programme of survey and excavation was initiated at what appeared to be one of the earliest foci for the early medieval reclamation: one of a number of oval-shated enclosures known as infiekls. These features are not uncommon on the higher, coastal parts of the reclamed saltmatrshes on both sides of the Severn Estuaty, and it has been argued that they represent the earliest statges of matshland reclamation. With the oval shape resulting from their having been enclosed in at relatively open landscape, thus being unconstrained by existing landscape features (Rippon 1997. figs $+48+5$ ). 'The sites have a number of common characteristics. They are often associated with field-names indicative of early medieval habitation (e's. Worth' and huish'). lie close to medieval churches chapels. and have surface finds of medieval and/or Roman pottery. Many are also asseriated with extant famsteads though, like the churches chapels, these almost invariably lie comards the edges of the enclosed arcal.

The example chosen for detailed investigation wats Church rield in Puxton, $9 \mathrm{~km}$ east of Weston-super-Mare (Fig. 2). The site has now been subjected to earthwork, resistivity and fiekdwalking surveys along with trial excalvations (fig. 3) which have yielded samples for palacoenvironmental analysis (Rippon 1906: 1907: 1998: 1999). In addition, soil samples were also taken from the whole of the infield together with a fiedd to the south. and it is the results of the chemical analysis of these samples that are reported here. Although there is no cvidence for an habitative field-name. Puxton otherwise conforms to the type description of an inficld with a church and hamket located on its northern edge. When ploughed during the log(t)s the field revealed Romano-British and medicval pottery, and though considerably denuded by recent ploughing there survive the eathworts of a coherent patters of rectilineatr platforms and enclosures suggestive of an areal of abandoned scttement (Fig. 3).

The smaller but more pronounced platforms lay to the noth notherast of the inficld and are suggestive of house platforms, the highest of which lies immediately to the south-east of the church. When fietdwalked, this area produced the greatest amount of medieval building debris (stone. burnt clay/datub. etc) and kitchen refuse (animal bone. pottery, etc), and excatration (Trenches 2 \& 12 ) revealed a deep sequence of occupation clebris dating to beween the tenth and thirteenth centuries. The enclosures in the southern and westem parts of the infiedd are larger and defined by slighter ditches, and ate more sugegestive of the padelockis that chuster around traditional farms even today being used as gardens. orchards and yards for livestock. The 


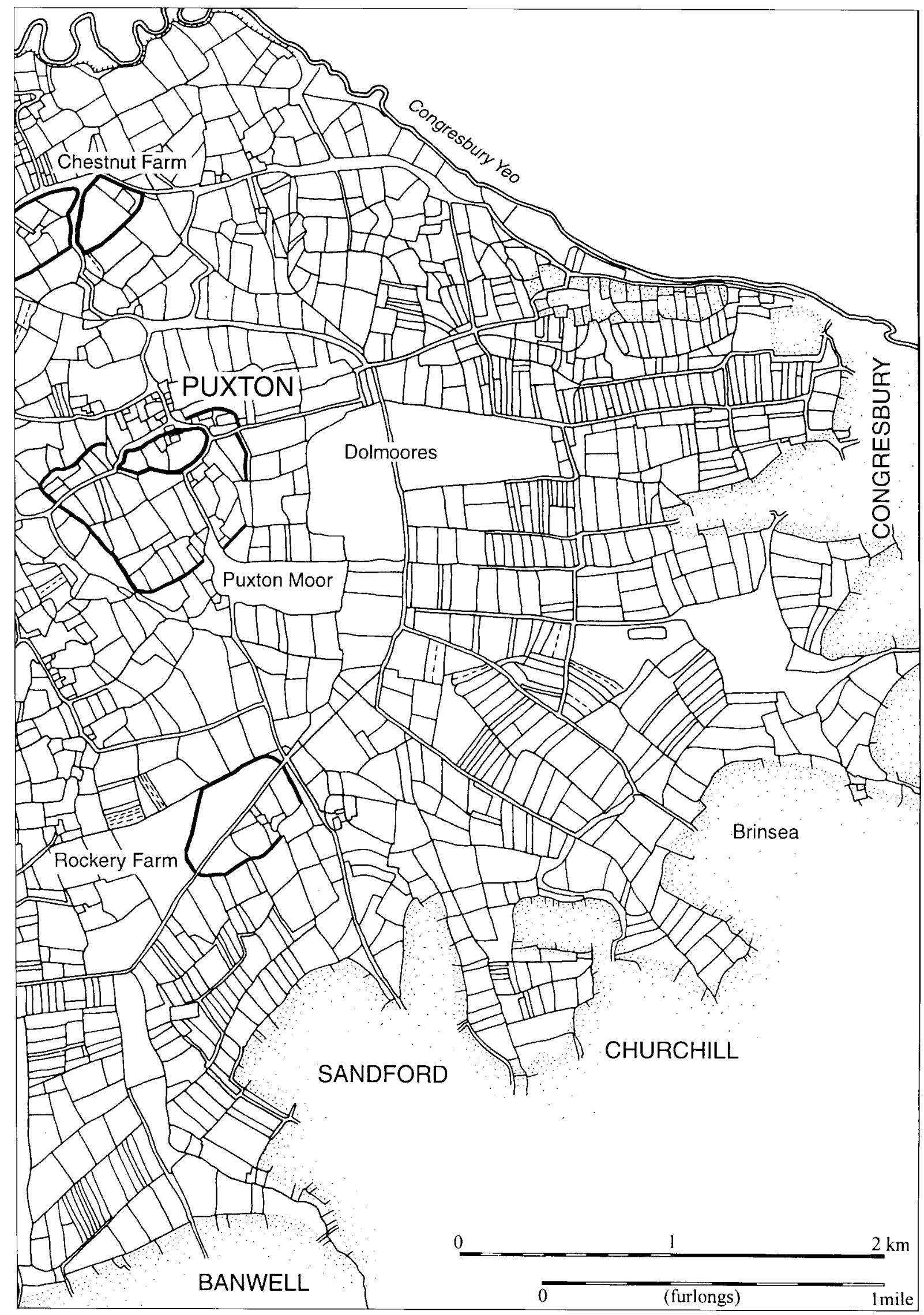

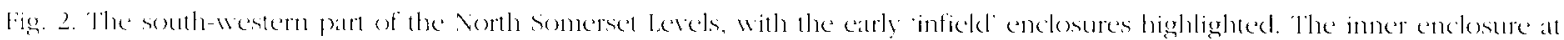

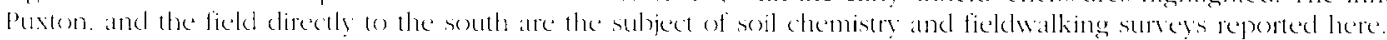




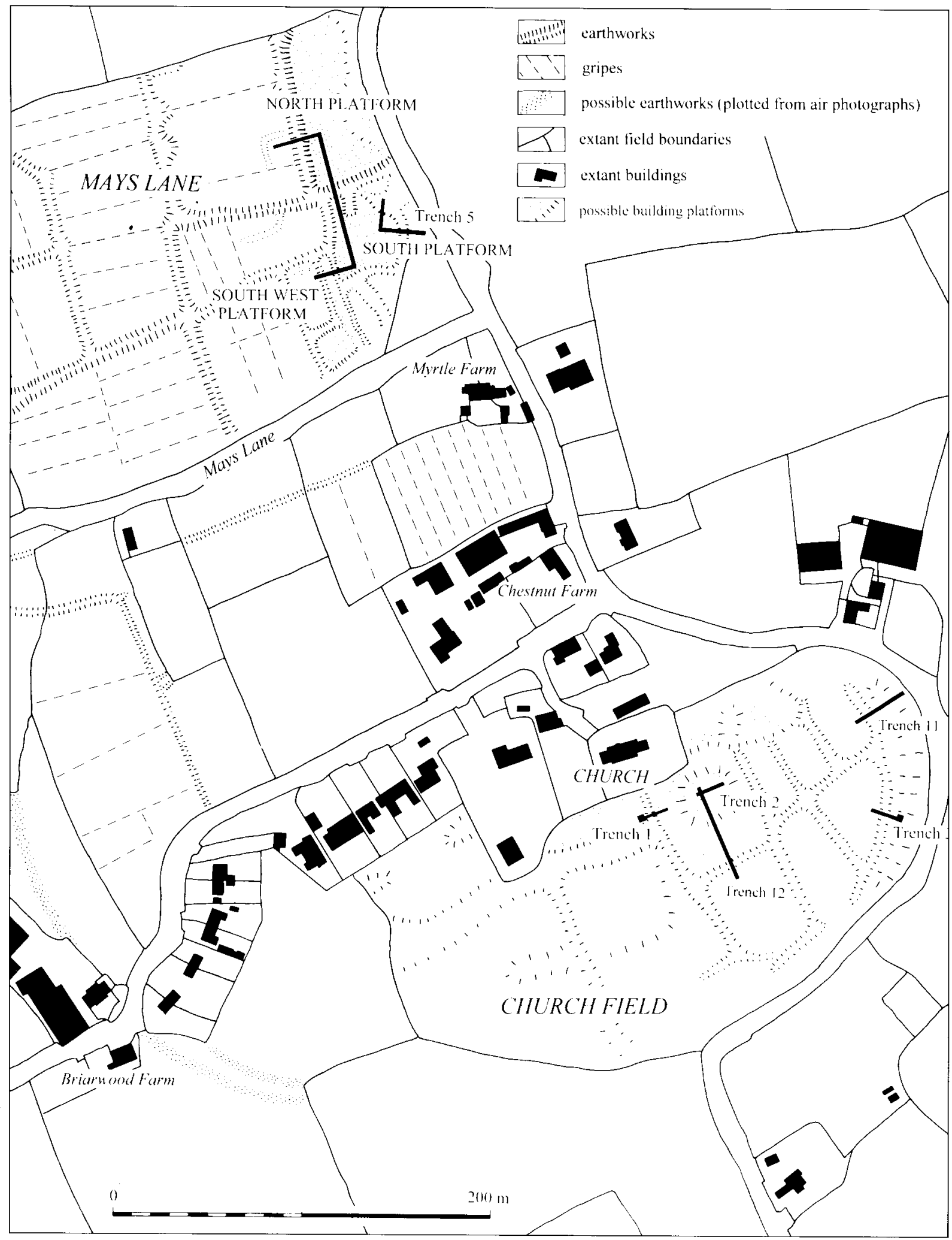

Fig. 3. Shronken settement earthwortis at Puxton, and the location of excavated trenches. 
fieldwalking survey produced a light scatter of medieval material (Fig. 16) suggestive of kitchen rubbish and farmyard manure being spread over the paddocks in order to increase fertility. To the south-west of the church there is a pronounced circular depression which, when fieldwalked, yiedeled large amounts of post-medieval material suggestive of a former pond that has been partly backfilled in recent times. The eastern, southern and westem edges of the 'infield' enclosure are marked by an extant field drain, inside which there are traces of a concentric bank and inner ditch (sectioned in Trenches 3 \& 11 ).

The ficldwalking survey also produced Romano-British and post-medieval pottery (Figs 15 and 17). The former was a very light scatter over much of Church Field, indicative of no more than the spreading of farmyard manure over ficlds. Larger amounts of post-medieval pottery were recovered, concentrated in the nothern and north-western areas, inclicative of manuring and the dumping of material over the ends of back gardens in the extant village. A very discrete concentration of post-medieval debris also occurred in and around the slight clepression of a former pond and indicates its recent partial back-filling.

\section{SOIL COMPOSITION AND HUMAN ACTIVITY}

The survival of earthworks, and the presence of ploughing that allowed the systematic surface collection of artefacts, means that a consiclerable amount can be said about different activity zones within the infield, and this has now been confirmed through small-scale yet carefully targeted excavations. However, if the earthworks had been ploughed that, and the site then returned to pasture, there would have been no evidence on the surface as to the nature of this site, or any inclication of where to excavate. As geoplysical survey is notoriously unsuccessful on alluvial soils, another method of prospection needs to be developed for use in such circumstances.

As described above, the puxton data suggested that a number of discrete activity zones could be identified within the infield': an area of domestic occupation and midden dumping south-east of the church, the occasional manuring of small enclosures used for horticulture, orchards, and paddocks for stalling livestock elsewhere in the 'infield', and an area of recent dumping in the circular hollow. Based on this existing knowledge, the relatively untried technicule of heavy metal analysis was used, alongside. the well-established phosphate analysis and magnetic susceptibility, in order to test its success on a site where patterns of activity were already relatively well understood.

The elemental composition of soils is influenced primarily by the nature and weathering of the parent material and the incorporation of anthropogenic organic matter through bioturbation. Many other factors also affect or disturb that chemical composition, including the addition of agricultural fertilisers. cropping, and other past uses of the land. The hypothesis tested here was whether existing patterns of soil chemistry are linked to past human activity. The magnetic properties of topsoil can be affected by a series of processes, some physical, some biological. The magnetic nature of top soils may also be influenced by aterial contamination. Not all these processes are fully understood, but it is generally found that soils taken from the surface layers give stronger magnetic signals than those from the subsoil. Of more relevance to this study is the hypothesis that laboratory analysis of surface samples will give some inclication of localised enhancements that may be attributable to burning, burned or otherwise oxidised material, or to topsoil/subsoil mixing (buried ditches, eroded banks etc) that has been rendered more magnetically susceptible.

Analysis of soils for phosphorus accumulations associated with sites of human occupation has been practised for many years since the pioneering work by Olaf Arrhenius in the late 1920s (Arrhenius 1929). Although such evaluations have been known in certain circumstances to give inconsistent results (e.g. shallow upland soils which vary markedly in clepth and texture - see Crowther 1997), in the deeper and texturally more consistent lowland alluvial soils of North Somerset this would be unlikely.

It was initially considered that the measurement of organic carbon content of soils as an indicator of past human activity might be compromised by its usually high turnover rate in the soil. However, associations of areas of dark soils with ancient settlements (e.g. in field-names such as 'blacklands') have been shown to be connected with elevated levels of organic carbon (Aston et al. 19981)). Incleed, work at Rothamsted Experimental Station over twenty years ago (Jenkinson \& Ralyner 1977) gave credence to the longevity of residual levels of organic carbon in arable soils. The use of loss on ignition as a measurement of organic carbon was based on the improved methodology of Ball (1964).

The ways that soil heavy metal concentrations could have been altered by human activities in the past has been described elsewhere (Aston ot al. 1998a; 1998b) and these include, as with phosphorus and organic carbon, enrichment of soils through urine and faeces in the form of refuse dumping, cess-pits, middens, stored produce and animal housing, along with the use of fires/hearths, metalworking and other processing such as leather making and crop processing (e.g. winnowing and retting). As far as food consumption is concerned it has been 
shown that the daily intake and excretion rates of a selected range of metals and phosphorus for an aretage human being ate significant (Snycler (d al. 1975). Four elements phosphorus, zince manganese and eopper) show very high rates of intake and excretions nickel and lead show intermediate ketels; while cadmium, chromium and cobalt show relatively low levels. The intake and excretion rates of the dements will, of course, vary with diet. 'There is evidenee that ancient diets (Roman and medieval) contained a much higher lead content that those of the present day (Cillialan 1965: Vriagu 1983). Aston et al. (1098a: 1098h) and fackson (2001) have presented ad boe calculations showing the relative effect of human falecal material on soil ckemental composition and have shown the relative entichment of soils based on alverage concentrations in 'normal' soils. In a similar way, burning of wood for fires used in valrious activities would have also resulted in an accumblation of wooki-ash which, relative to soil, would be enriched in many metals originating from the normal chemical compesition of plants used as fuel.

\section{MET'TIOI)()L()(i)}

In this survey. the inlield enclosure at puxton (church ficeld) was the main focus of attention, althergh a second ficld to the south that lay outside the enclosure was also sampled. The latter was included becaluse it was felt important to sample an areal wider than that of the main focus of interest in ordere to obtain a range of meastruments that would be both active and inactive archateologically: samples from the ficld to the south would, it was hoped. provide an objective comparison with natural or. at least, less disturbed, background levels of soil factors. 'There are no risible earthworks in the field to the south of Church Fickd and ficldwalking produced far ferver finds. No excavations were carried out.

A number of factors need to be considered before the use of heary metal analysis of soils can be taken as a reasonable tool in archacelogical research. some of which will influence chosice of metals or analytical method, while others highlight allernative explanations of distributional patterns (see Jackson 2001). In this case study, one of these factors, variations in soil chemistry dee to the underlying geology. is not a problem since the entire site all Puxton lies on a uniform estuarine alluvium. Vearly $3(0)$ soil simples were collected firom the lop soil on a 20 metre grid latid out over both fickds. Organic carbon was estimated by loss on ignition and mannetic susceptibility measureel in the laboratory on air-dried soil. Total phosplotorus (spectoplosometry) and heary metal assalys (atomic alsorption spectrometry) were made following digestion of suls-samples in nitric acid. Full details of the methodology employed and analytical procedures followed are described elsewhere (Aston of al 1908at: 1998b).

\section{RESL TLIS}

The geographical variation orer Church fiekl and the fiekl to the south in soil concentrations of magnetic susceptibility perecentalese loss on ignition (organic matter), phosplonus, and eight individual leary metals (meg per gram of soil), are presented below as isoline malps ( Figs - t-1 t). Plots for the distribution of Roman, medieval and post-medieval pottery (number of sherds per 20)metre transect) recorefeel by fieldwalking are also illustrated (Figs 15-17). Spatial interpolation follows specifications in a standard statistical

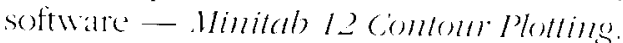

Hagnelic susceptibility: the most notic(uab)e enhanecment of magnetic susceptibility lies c. 100 metres to the south-rest of the church and coincicles with the small circular hollow revealed by the earthwork survey (a former pond) and a matred concentration of post-medieval debris indicative of recent dumping (bigs $t$ and 17 ). Otherwise there is a more gencralised paltern over the two fields although there appear to be some patrallels with coppere and rinc.

loss on igmition (used to estimate organic (arbon): there are scattered peaks and troughos of organic carbon entichment mostly in the central and eastern parts of the Church field with an outlying patch to the north-west. Similar concentrations occur within the field to the south of Church field although these diminish southwards (Fig. 5). Within Church Field, the soil samples that lost most orgatnic carbon on ignition at $150^{\circ} \mathrm{C}$ were close to and just to the south of areas that the earthworks, resistivity survey. fieldwalking and excalvation suggest correspond to the main focus of oxcupation. I Jow exert. other peaks are located in atreas considered to be outside the primary settlement area as stech and may result from localised waterlogging in the winter months or where soils are naturally more peaty. They maly. of course, arise from leci of as yet. unidentified human activity

Phosphorts: the highest concentrations of phosphoress are found on the raised plattorm to the south-east of the church which appears to have been the main focus of occupation. Concentrations in the ficld to the south of Church Ficeld were relatively low (Fig o)

Lead: the highest levels of lead are found in the centre of church field and, like phosploners, are mainly concentrated on the raised platform te) the southerast of the Church. There are also small patches of lead-rich soil to the west and south of this central areal and a larger palteh of 


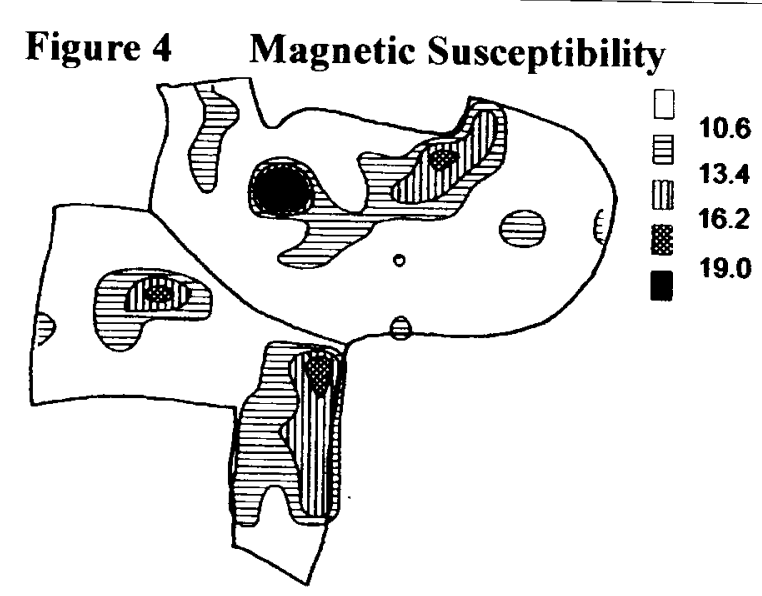

Figure 6 Phosphorus
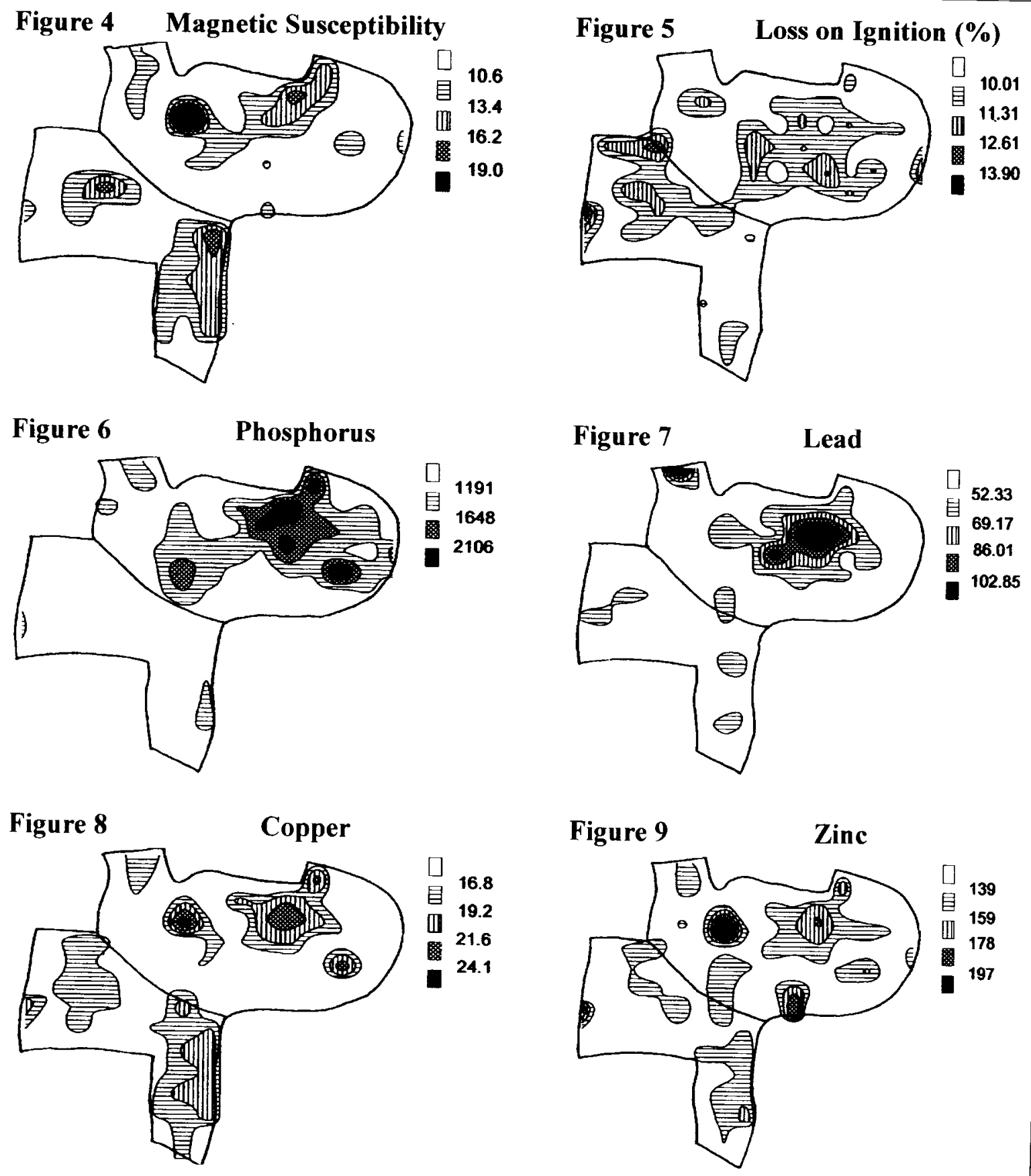

Figure 10

Cadmium
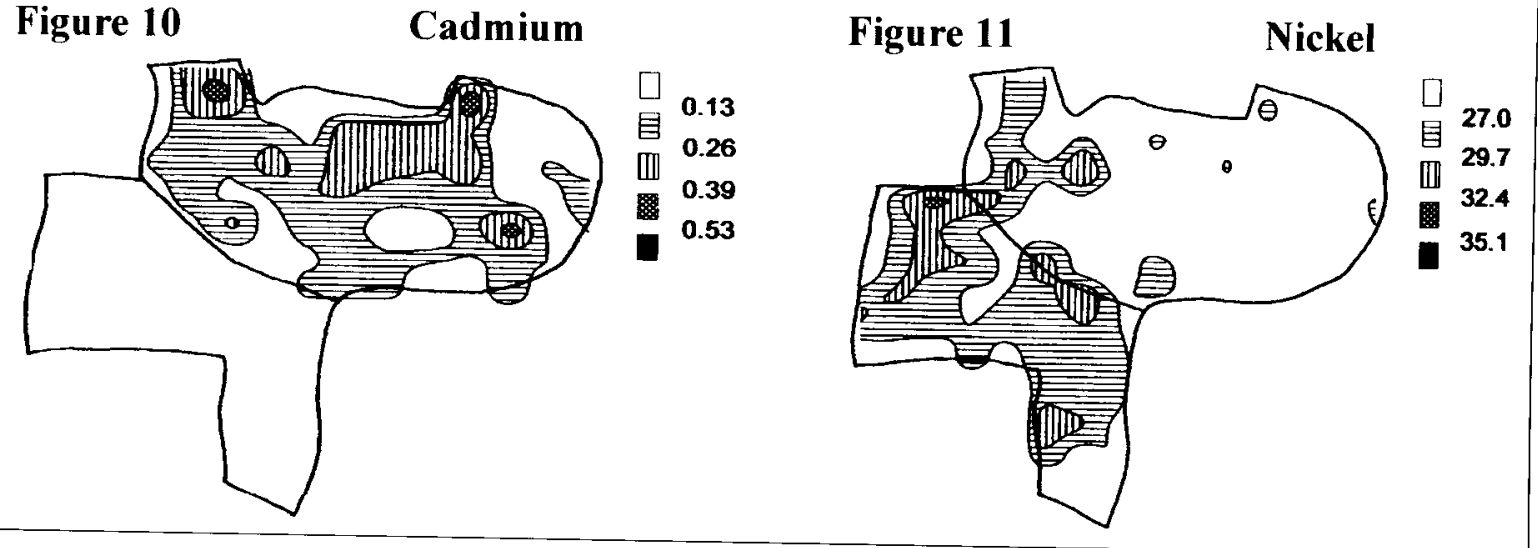

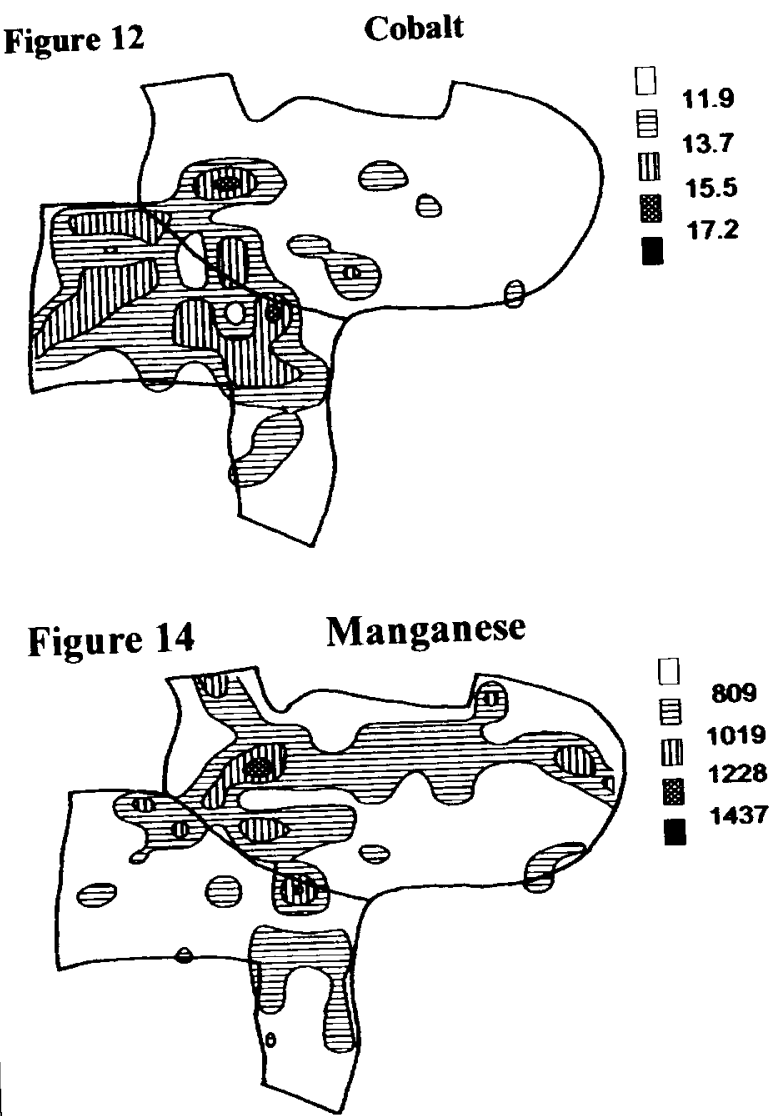

Figure 16 Medieval Pottery

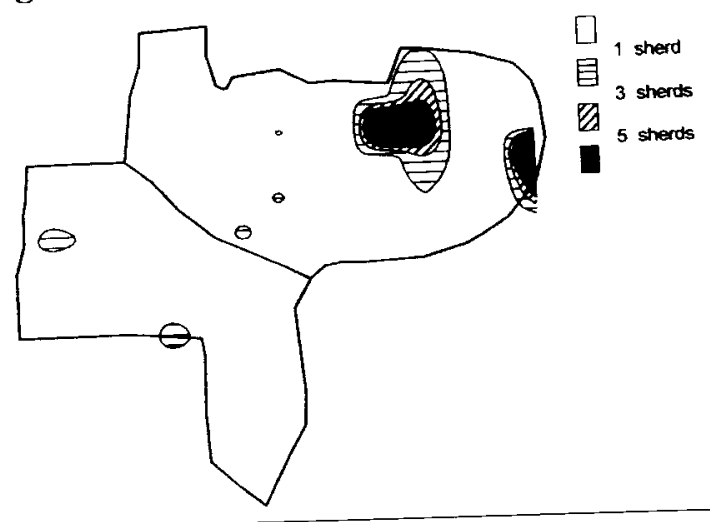

Iigs 12-17.

enhancement to the north-west which does not appear to correlate with any indication of medieval occupation. The distribution of postmedieval pottery suggests that this was an area of rubbish dumping. Minor concentrations of lead also occur within the field to the south of Church riekd, matching those of copper and zinc, though the levels are much lower than in Church pield itself (Fig. 7).

copper: the levels of copper are not exceptionally high but higher concentrations can be found on the raised platform south-east of the church, and over the former pond. Lower
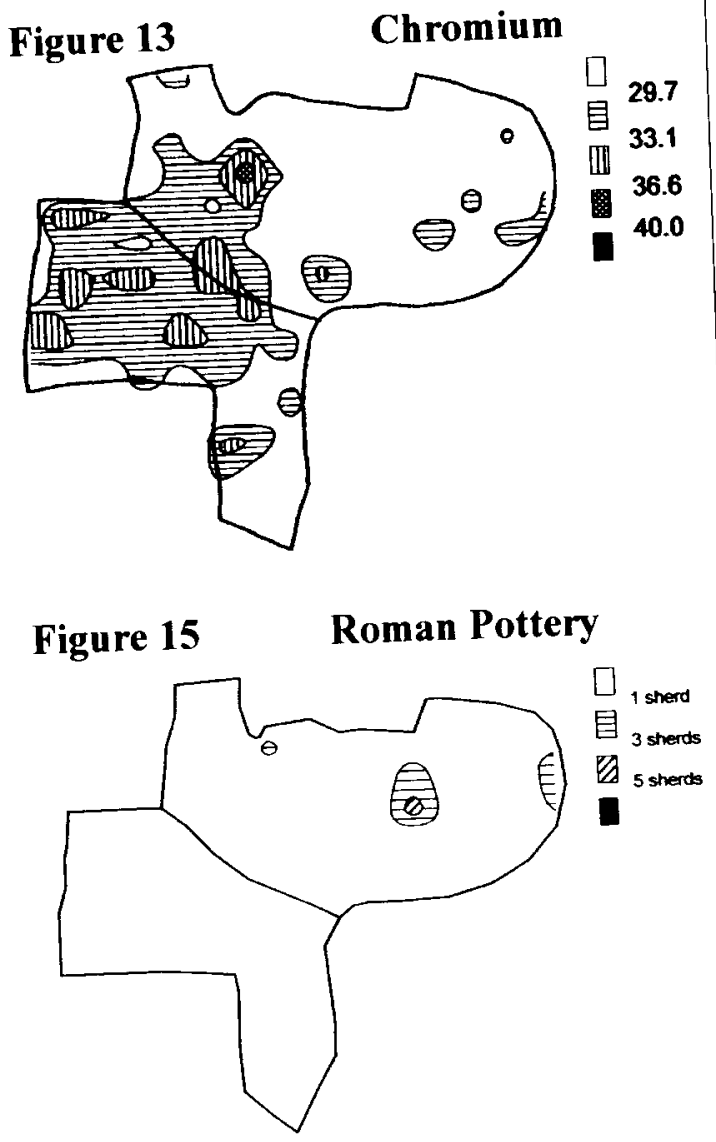

Figure 17 Post-medieval Pottery

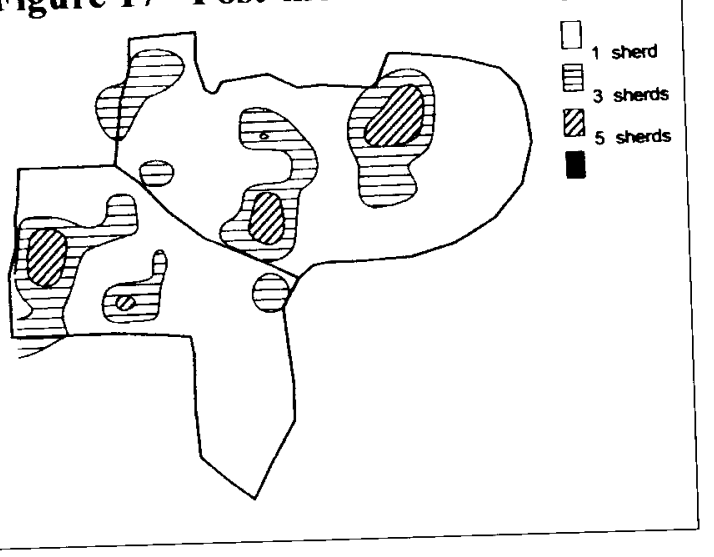

concentrations are found in the field to the south of Church Field (Fig. 8). These areas of greater copper entichment match those of leakl, zinc and cadmium, and appear to relate to settlementrelated activity, and the backfilling of the former pond.

Zinc: the pattern of zinc-rich soils is more dispersed than lead, but has a broadly similar distribution. There is a matked concentration c. 100 metres south-west of the church corresponding to the former pond with its high magnetic susceptibility and post-medieval debris (Fig. 9). 
Cadmiam: the distribution of calmium-rich soils is confined to Church Ficld itself, although these levels, it must be said, are not particularly high (Fig. 10). The distribution is broally similat to lead and zinc with concentrations on the raised platform south-calst of the church, in the north-west of Church Field, and over the former pond.

Nickel (Fig. 11), Cobalt (Fig. 12) and Chromium (Fig. 13): the distribution of soils with higher levels of nickel, cobalt and chromium all concentrate in the western part of Church Field, including over the former pond, and over much of the fiekd to the south of Church Field. This pattern appears to show a matred negative correlation with the distribution of phosphorus, lead, zinc, cadmium and copper, and the other indicators of medieval occupation. An explanation for this is suggested below.

Manganese: discrete patches of manganeserich soil are dispersed widely over the sampled area with no strong correlation to any other elements or the known patterns of human activity (Fig. 14).

\section{ANALYSIS OF DATA}

Variation in the values of mannetic susceptibility, loss on ignition, heavy metals and phosphorus recorded in soils taken from Church Field and the field to the south of Church rield are presented below (Table 1). Some comparisons are presented between the settlement field (Church Field) and the relatively less disturled field to the south. The data from Church rield are then considered in more detail.

Simple statistical analysis generally confirmed the patterns revealed in the isoline plots. Church Field contained greater mean soil concentrations of phosphorus, lead and zinc, whereas the field to the south was richer in nickel, cobralt and chromium $(p=0.001)$. In terms of localised elevated enhancements, those for magnetic susceptibility, phosphorus, lead, zinc and copper all occurred in Church Field, whereas those for nickel, colxalt and chromium were to be found in the field to the south (see kurtosis and skewness values in Table 2). Soil concentrations of oroanic carbon (as measured by loss on ignition) and manganese failed to demonstrate much in the waly of a between-field variation.

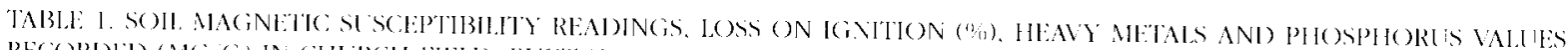

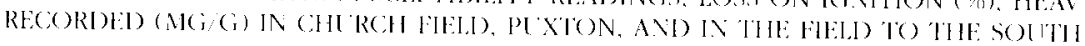

\begin{tabular}{|c|c|c|c|c|c|c|}
\hline \multirow[t]{2}{*}{ Mecistuement } & \multicolumn{3}{|c|}{ Charch Ficld } & \multicolumn{3}{|c|}{ Fineld to the south } \\
\hline & minimum & maximum & mean & minimum & maximum & mean \\
\hline Magnetic Susceptibility & y 6 & 30 & 11 & 7 & 18 & 11 \\
\hline Loss on Ignition & 7 & 13 & 10 & 7 & 15 & 10 \\
\hline Phosphorus & 551 & 2672 & 1300 & 410 & 1476 & 828 \\
\hline Lead & 32.0 & 154 & 55.9 & 39.0 & 76.1 & 47.0 \\
\hline Zinc & 102 & 298 & 141 & 98 & 201 & 136 \\
\hline Cadmium & 0.1 & 0.5 & 0.2 & 0.1 & 0.8 & 0.3 \\
\hline Copper & 10.3 & 25.6 & 16.4 & 13.9 & 21.9 & 17.5 \\
\hline Nickel & 20.6 & 33.4 & 26.0 & 23.4 & 34.4 & 28.4 \\
\hline Cobalt & 8.3 & 16.4 & 11.2 & 9.1 & 17.3 & 12.9 \\
\hline Chromium & 20.0 & 38.9 & 29.0 & 22.6 & 40.6 & 30.8 \\
\hline Manganese & 273 & 1508 & 868 & 435 & 1493 & 760 \\
\hline
\end{tabular}

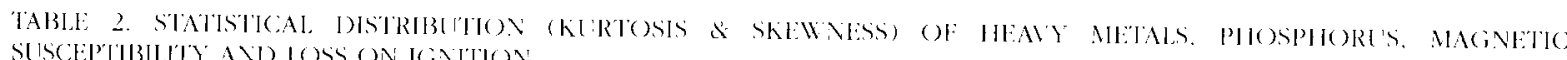

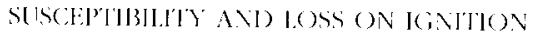

\begin{tabular}{|c|c|c|c|c|}
\hline \multirow[t]{2}{*}{ likement } & \multicolumn{2}{|c|}{ Chullo field } & \multicolumn{2}{|c|}{ Ficld to the soluth } \\
\hline & kurtosis & skewness & kurtosis & skewness \\
\hline Magnetic Susceptibility & 12.03 & 2.92 & 2.09 & 1.45 \\
\hline Loss on Ignition & -0.12 & 0.20 & 0.66 & 0.40 \\
\hline Phosphorus & 1.37 & 1.11 & 0.75 & 0.88 \\
\hline Lead & 6.95 & 2.46 & 5.67 & 1.93 \\
\hline Zinc & 22.20 & 3.51 & 1.29 & 0.68 \\
\hline Cadelmium & -0.45 & 0.49 & 0.51 & 0.56 \\
\hline Copper & 0.39 & 0.56 & -0.60 & 0.34 \\
\hline Nickel & -0.11 & 0.36 & $-(0.34$ & 0.06 \\
\hline Cobalt & 0.62 & 0.70 & -0.18 & 0.40 \\
\hline Chromium & -0.02 & 0.15 & -0.34 & -0.23 \\
\hline Manganese & 0.16 & 0.08 & 0.81 & 0.86 \\
\hline
\end{tabular}


TABIE 3. (ORRELATION (PLARSON) ANALYSIS

\begin{tabular}{|c|c|c|c|c|c|c|c|c|c|c|}
\hline LOI & $\begin{array}{c}\text { MS } \\
-0.015\end{array}$ & I.()। & Plesphorus & Lcaid & Copper & Zinc & Cadmiun & Vickel & (c)lyalt & (hhromium \\
\hline Phosphorus & 0.213 & 0.085 & & & & & & & & \\
\hline Lexad & 0.261 & 0.170 & 0.461 & & & & & & & \\
\hline Copper & 0.433 & 0.172 & 0.338 & 0.467 & & & & & & \\
\hline Zinc & 0.452 & 0.141 & 0.399 & 0.398 & 0.641 & & & & & \\
\hline Cadmium & 0.161 & -0.012 & 0.690 & 0.398 & 0.152 & 0.291 & & & & \\
\hline Nickel & 0.133 & -0.162 & -0.327 & -0.134 & 0.281 & 0.177 & -0.265 & & & \\
\hline Cobalt & -0.055 & -0.107 & -0.395 & -0.140 & 0.095 & -0.004 & -0.324 & 0.626 & & \\
\hline Chromium & 0.046 & -0.041 & -0.231 & -0.170 & 0.110 & 0.150 & -0.211 & 0.728 & 0.562 & \\
\hline Mangancese & 0.112 & -0.355 & 0.234 & 0.186 & 0.209 & 0.190 & 0.289 & 0.347 & 0.357 & 0.113 \\
\hline
\end{tabular}

The apparent similarities between certain distributions can also be tested statistically. Correlation analysis of soils from Church Field ( see 'Table 3) show a significant $(p=0.001)$ association of phosphorus with lead, copper, zinc and cadmium. Copper and zinc concentrations also correlated $(\mathrm{p}=0.001)$ with the more magnetically susceptible soils. Soil concentrations of nickel, cobalt and chromium (and manganese) were all clearly associated $(p=$ $0.001)$ but negatively correlated (not manganese) with phosphorus.

The cluster analysis dendrogram (Fig. 18) of the soils taken from Church Field graphically demonstrate these correlations.

This segregation into a phosphorusdominant, site-positive group of soil factors and a nickel-dominant, site-negative group of soil factors has been evident in other archateological soil investigations in the British Isles (Jackson 1997; 2001). Both groupings are argued to be anthropogenic in origin, the site-negative nature of certain soil factors being attributed to a dilution effect by more aggressively generated (or possibly more soil persistent) soil clements.

An unusual feature at the Puxton site is the relative ambiguity of the loss on ignition results. At most other sites investigated (Jackson 2001) soils rich in residual organic carbon were clearly site positive and strongly linked with phosphorus-rich soils. No explanation for this inconsistency at Puxton is as yet fortheoming.

Statistical analysis of soils from the fiedd to the south of Church Field (not presented) show similar correlations. This is not surprising considering its proximity to the medieval settlement. Indeed, few soils in lowland Britain are likely unaffected by past human aletivities.

The essential nature of the technique, as it is presented here, is in its potential for site prospection and the identification of foci of past human activity, and hence it is the relative spatial distribution (as displayed in the isoline maps) of the measured soil properties that matters. Plotting site-positive data and site-negative data as aggregated isoline maps has proved a useful

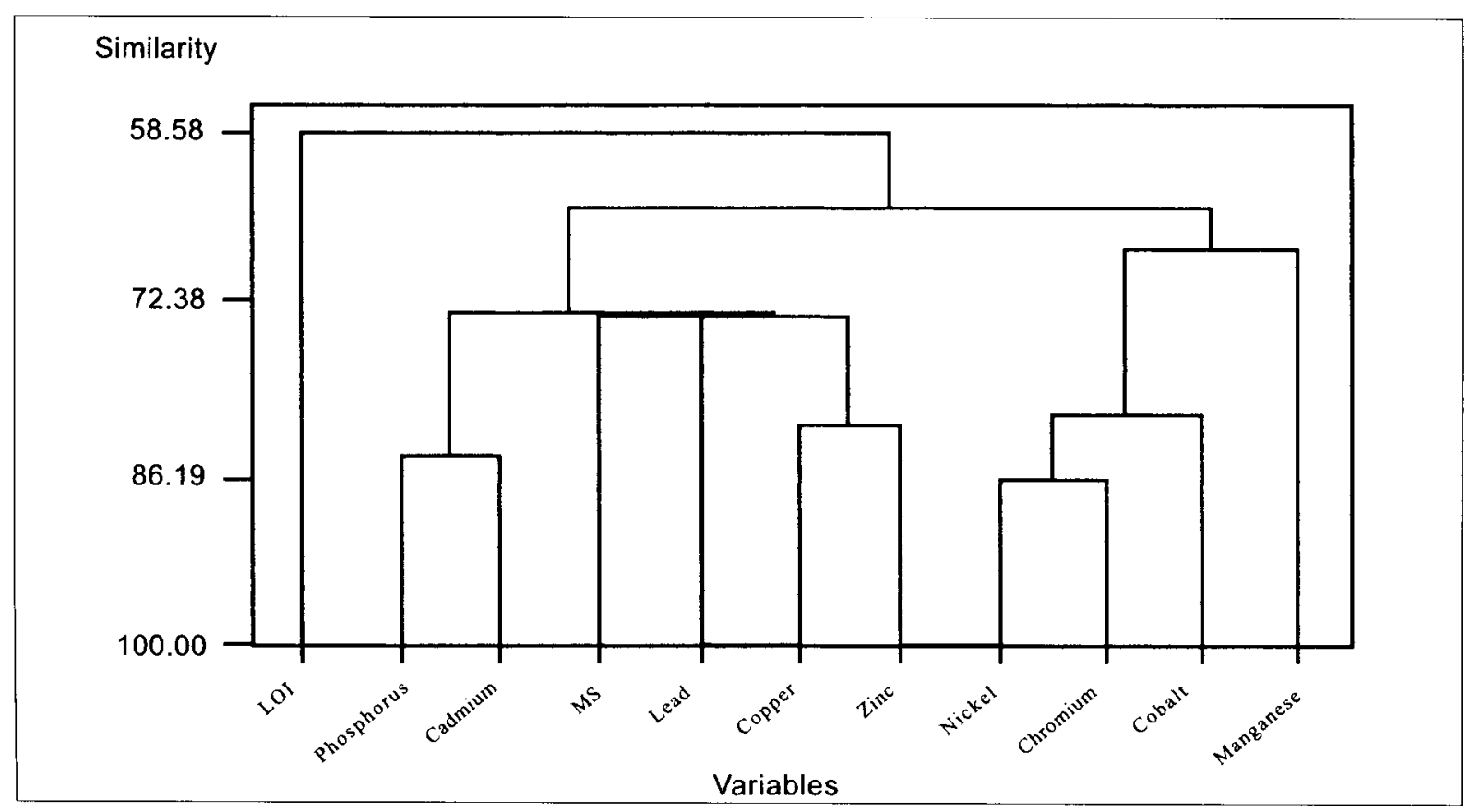

Fig. 18. Chuster analysis clendrogram. 
means of locating, confirming or extending potential areas of archaeological investigation (Jackson 2001). Figs 19 and 20 illustrate this procedure appliced at Puxton.

The interpretive potential of soil analysis data is not confined to prospection and some initial work on identifying the activities that may have contributed to the surviving residues has been reported elsewhere (ibid.). At Puxton, the geochemistry suggests zones of different activities and these are discussed below.

\section{IISCLSSION}

The programme of survey and excavation at Puxton allows the results of soil chemistry analysis to be compared with a wide range of other clata in order to reconstruct a number of activity zones in and around a medieval settlement. Earthwork survey, fiekdwalking and excavation suggests that the main focus of occupation within an oval-shaped enclosure lay on the raised platform some 50 metres south-east of the church, while during the medieval period the remaining parts of Church Field would appear to have been laid out as a series of small paddocks and enclosures that may have seen some manuring. The field to the south of Church Field lay outside the 'infield' and a lower intensity of human activity is to be expected at least in the carlier phases of the evolution of this landscape. Ficldwalking certainly produced far fewer artefacts and there are no settlementindicative carthworks. The spatial distribution of soils enhanced with magnetic susceptibility, phosphorus, lead, copper, cadmium, and zinc (and, to a lesser degree, organic carbon), would support this hypothesis

By contrast, soils comparatively rich in nickel, cobalt and chromium appear to be more concentrated in the southern and western palrts of Church Field and outside the enclosure in the field to the south. This apparent enhancement in the area peripheral to human settlement is, it is argued, due to the relative dilution of these metals within the settled area by more rapidly accumulating amounts of site-positive soil factors. Soils with increased levels of manganese similarly slowed a poor correlation with the known archaeology but did not fall comfortably into either of the above groupings. Manganese deposition is often associated with areas prone to waterlogging or a water retentive area.

Apart from the main focus of medieval settlement to the south-east of the church, there are two localised areas which produced relatively high readings for a number of elements. A small hollow to the south-west of the church appears to represent a recently backfilled pond. Large amounts of post-medieval debris were recovered through the fieldwalking survey, and the area had enhanced magnetic susceptibility (indicating the deposition of burnt material) and concentrations of copper, zinc, cadmium, nickel and chromium. The other area with relatively high values for a number of elements lay to the north-west of Church Field and appears to correlate with an area in which refuse has been clumped over the backs of gardens also cluring the post-medieval period.

It would appear, therefore, that both medieval occupation and post-medieval dumping can produce very similar chemical signatures in the soil chemistry, and that other survey techniques are required in order to distinguish the two. However, this work confirms that magnetic susceptibility and phosphorus indicate intense occupation and associated midden dumping, though now several heavy metals (lead, cadmium, copper and zinc) can be added to this list.

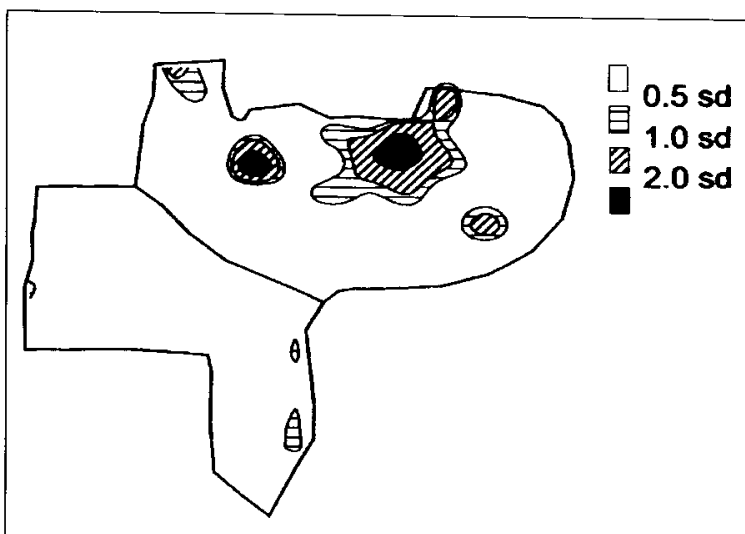

Fig. 19. Site-positive factors.

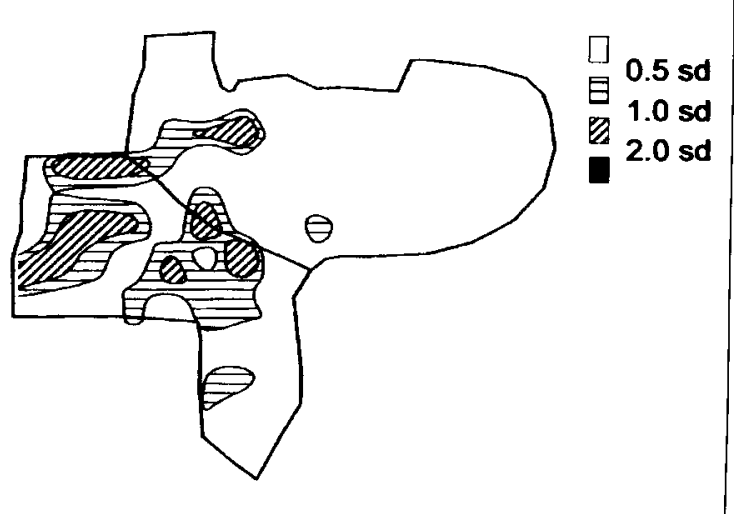

Fig. 20. Site-negative factors. 


\section{ACKNOWIEDCIFMENTS}

The authors would like to express the thanks to Mr Derek Mead for allowing ws to undertake the fieldwork, which was generously funded by the British Acaclemy, the Maltwoed
Fund the Royal Archateological Institues, Society of Antiquaties, and the Iniversities of Bristel. Lixeter and Realing

1. Measurements of mannetic susceptibility are comparative and therefore dimensionless.

\section{BIBLIOGRAPIY}

Arrhenius, ()., 1929. '1)ice phosphatfalge, Zeitschrift fior

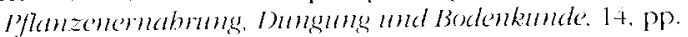
$185-6 \cdot 4$

Aston. M. A. Martin. M. 11. \& fackson. A. W. 1998a. The use of heary metal soil analysis for archateological surveying". chemosphere. 37. pp. 465-77.

Aston, M. A. Martin. M. H. \& Jakkson, A. W., 1998h. "The potential for heavy metal soil analysis on low statts archaedogical sites at Shapwick, Somerset. Antiquity: 72 (278) $\mathrm{pp} .838-47$.

Ball. D). F., 1964. 'Loss-on-ignition als an estimate of organic matler and organic carbon in mon-calcarecess soils, f soil Sci. 15, 1, pp, sit-9)

Bethell. P. H. \& Mate. I., 1989). The use of soil phesphate analysis in atrohateology: a critique in Scientific Analysis in Archaeslogen ed. I. Henderson. Oxford Liniv comm Archated Monogr No 19. Pp. 1-29.

Bowen. H. I. M. 1979), Emirommental chemistry of the likments (loondon)

Crowther, J., 1907. Soil phosplate surveys: critical approaches to simpling. analysis and interpretation' Archacel Prospect + t. pp. 93-102

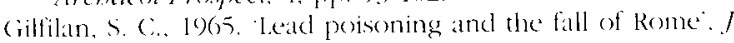
(xilp. Hed. 7. pp. 53-60)

fackson. A. W. 1997. The application of geo-chemical soil analysis to interpret early historical landscapes in somersed, unpubl I'niv laristol M.A. Diss.

lackison. A. W., 2001. Heavy metals in archacedogy - an cvaluation of chemical residues in the soil associated with past human activity, unpubl I niv Bristol Ph.l). thesis.
Jenkingen 1) s \& Rayner. I. H., 1977. "The turnower of soil organic matter in some of the Rothamsted classical experiments, soil sot, 23. pp. 298-305.

viragu. I. O.. 1983. Lead and Lead Pobsoning in Antiquity (New Yorts).

Rippon $s, 1006$. Roman and mediexal settlement on the North somerset Levels: survey and excavation at Banwell

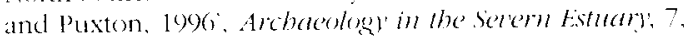
Pp. 39-52.

Rippon. S., 1097. Roman and medieval sedtlement on the North Sometset levels: the second season of survey and excatation al Banwell and Puxton. 1997. Archaedogl in

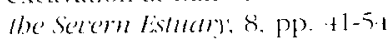

Rippon, s. 1008. Necieval settement on the North somerset lecels: the third season of survey and exatation at

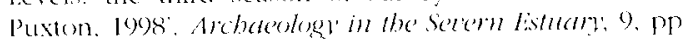
(6) -78 .

Rippom, S., 1909) Medieval settlement on the vorth someriset Lerels: the forrth reatson of survey and excaration at

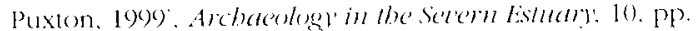
$65-73$.

Rippon. $\mathrm{s}$. 2000, "The Romano-British exploitation of coastal werlands: survey and excavation on the North somerset levels. 199)3-7, Brikmmia 31, pp. (6)-200.

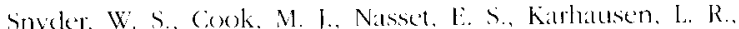
Parry Howells. (i., \& Tipten, 1. H., 1975. Repont of the

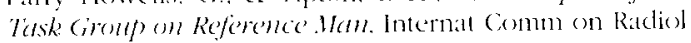
Prot $\mathrm{N}(\mathrm{s} 23(0 \mathrm{xford})$. 